\title{
Gharacteristics of Khumbu Glacier, Nepal Himalaya: recent change in the debris-covered area
}

\author{
M. Nakawo, H. Yabuki, A. Sakai \\ Institute for Hydrospheric-Atmospheric Sciences, Nagoya University, Furo-cho, Chikusa-ku, Nagoya 464-8601, Japan
}

\begin{abstract}
Using satellite data, the longitudinal distribution of the ablation rate and flow velocity were estimated for the ablation area, where glacier ice is covered with supraglacial debris. The ablation rate, small around Everest Base Camp (EBC) just below the equilibrium line, increased down-glacier for about $3 \mathrm{~km}$, then decreased gradually toward the apparent terminus, located about $10 \mathrm{~km}$ from EBC. The velocity decreased almost linearly from EBC to the terminus. The results allowed estimation of the recent change of ice thickness using the continuity equation. The glacier has thinned recently in the ablation area. The rate of thinning was large near EBC, where the surface is either bare ice or covered with very thin debris cover, but relatively small and rather uniform at lower sites, where the supraglacial debris layer was thick and supraglacial lakes and ice cliffs predominate. The general pattern is compatible with field observations.
\end{abstract}

\section{INTRODUCTION}

Most large glaciers in the Nepal Himalaya have ablation areas covered with debris. In contrast with debris-free glaciers, which are rather small, debris-covered glaciers several kilometers long are unique landscapes in the glaciated area. The change or evolution of these glaciers is of great interest and importance for water resources, as well as for tourism, particularly for assessing the effect of global warming on runoff in Himalayan catchments.

The melt rate of glacier ice underneath a supraglacial debris layer is rather small and it is difficult to detect changes to such glaciers by short-term observations. It is also relatively dangerous and difficult to carry out field observations because many big boulders are distributed over steep sloping surfaces and the debris thickness varies tremendously from place to place. Previous studies on debriscovered glaciers are hence very limited.

This paper discusses changes in a debris-covered glacier based on an estimate of the ablation rate underneath the debris layer using a heat-budget approach, and of the velocity distribution derived from analysis of satellite data.

\section{PREVIOUS WORK}

Khumbu Glacier, a typical debris-covered glacier more than $15 \mathrm{~km}$ long, drains mainly from the West Cwm between Mts Everest (Mt. Sagarmatha or Mt. Qomolangma), Lhotse and Nuptse in eastern Nepal. The elevation of the apparent terminus is about $4900 \mathrm{~m}$ a.s.l. The glacier has attracted much attention because it is located along a route to the highest peak of the world. The amount of information on the glacier is therefore large compared to other debris-covered glaciers.

Figure 1 shows a satellite image of the lower half of the glacier, covering the ablation area. West Cwm, the main accumulation basin lies to the east, and the glacier flows to the ablation area through an icefall just above Everest Base
Camp (EBC; $5300 \mathrm{~m}$ a.s.l.), where bare ice is exposed. The equilibrium line is just above EBC. There are many ice pinnacles up to $10 \mathrm{~m}$ high which extend downstream $2-3 \mathrm{~km}$

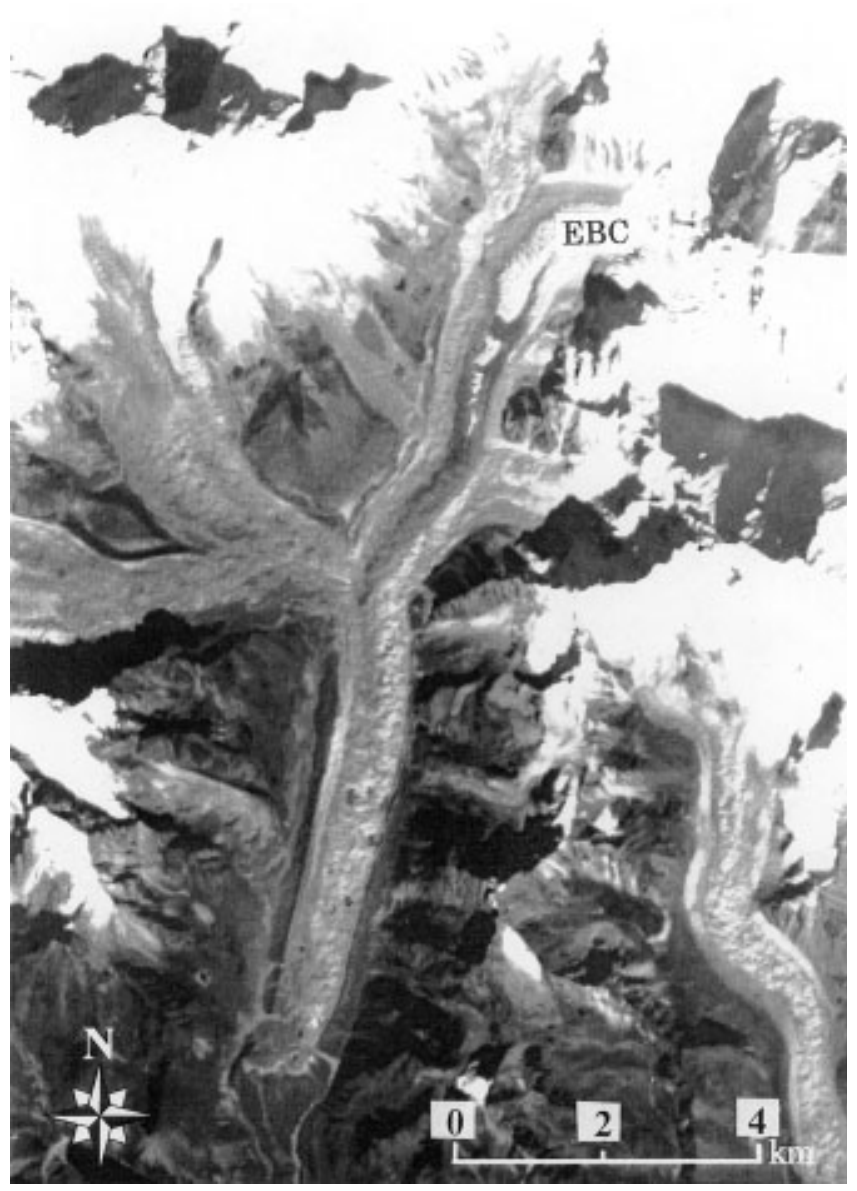

Fig. 1. Satellite multi-spectral image of Khumbu Glacier (SPOT HRV) taken 7 November 1995 (Scene ID: 3 227294, 04:52:30 1 xs). The pinnacle zone appears white extending downstream from Everest Base Camp (EBC) near the center of the glacier. 
below EBC. In the middle of the pinnacle zone, there is a transverse debris layer formed by a big landslide event, according to local people. Along the center-line of the glacier, supraglacial debris appears at the end of the pinnacle zone, increasing its thickness downstream (Nakawo and others, 1986). The debris consists of schistic rocks around the pinnacle zone and for a few kilometers downstream, but becomes granitic further downstream (Fushimi and others, 1980). The topographical characteristics of the glacier surface have been reported by Iwata and others (1980) and Watanabe and others (1986). Ice thickness was estimated by Kodama and Mae (1976) from surface velocity, and by Higuchi and others (1978) with an empirical equation. A direct measurement was made by Moribayashi (1978) using gravimetry.

Based on structural observations (Fushimi, 1977), the active terminus was considered to be about $3 \mathrm{~km}$ upstream from the apparent one, with a dead ice body in between. The velocity of the glacier has been measured by triangulation (Müller, 1968; Kodama and Mae, 1976) at several upstream sites. Recently, Seko and others (1998) obtained the velocity around EBC and the pinnacle zone by analyzing satellite images, and found, in comparison with previous results, that the velocity was decreasing.

The ablation rate observed by Müller (1968) was 0.02 $0.03 \mathrm{~m} \mathrm{~d}^{-1}$ at sites with bare ice surface and/or with very thin debris cover. Inoue and Yoshida (1980) reported an average ablation rate of about $0.02 \mathrm{~m} \mathrm{~d}^{-1}$, a similar value to Müller's, obtained at similar sites. They measured the ablation rate under a $1.2 \mathrm{~m}$ thick debris cover as well, and found it to be about $0.0015 \mathrm{~m} \mathrm{~d}^{-1}$, smaller by one order of magnitude. Although they noted much higher ablation at ice cliffs with thick debris, which generally surround supraglacial lakes in the area, they estimated an average ablation rate of 0.002 $0.004 \mathrm{~m} \mathrm{~d}^{-1}$ where thick debris cover was present.

\section{ANALYSIS OF SATELLITE DATA}

\section{Ablation}

The heat balance equation at the debris surface is given by

$$
C=F+H+E
$$

where $C, F, H$ and $E$ are conductive heat flux into the debris, radiation flux, sensible heat flux and latent heat flux, respectively. The values of $F, H$ and $E$ can be estimated with conventional equations using global radiation, air temperature, humidity, wind speed and cloud amount data, if surface temperature $T_{\mathrm{S}}$ is known (Nakawo and Young, 1981; 1982). Assuming a linear temperature gradient in the debris layer and $0^{\circ} \mathrm{C}$ at the debris-ice interface, $C$ is given by

$$
C=\frac{T_{\mathrm{s}}}{R}
$$

where $T_{\mathrm{S}}$ is in ${ }^{\circ} \mathrm{C}$ and $\mathrm{R}$ is the thermal resistance of the debris layer, defined as debris thickness divided by the thermal conductivity. The value for $R$ can be estimated by combining Equations (1) and (2). Once $R$ is known, the conductive heat flux $C$, for ice ablation for different periods, can be calculated by the same equations with meteorological data alone; without knowing $T_{\mathrm{s}}$, since $R$ can be regarded as constant at a site for a rather long time. This method for estimating ablation rate under a debris layer, proposed by Nakawo and others (1993), was tested successfully for Lirung Glacier, Nepal Himalaya, by Rana and others (1997), who estimated

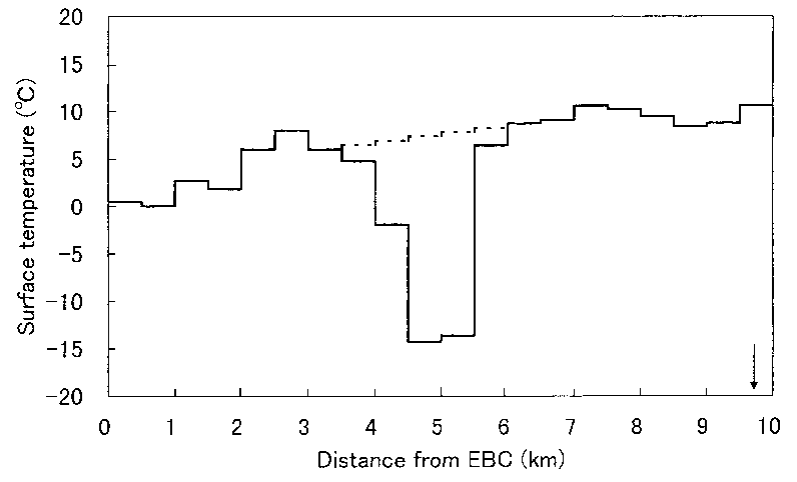

Fig. 2. Surface temperature averaged for every $0.5 \mathrm{~km}$ interval ( TM Band 6 of Landsat, 12 April 1988). Dotted line indicates interpolation for area shaded by cloud cover. Arrow shows apparent terminus of the glacier.

the surface temperature using satellite thermal-band data (e.g. Hall and others, 1987).

Figure 2 shows the longitudinal distribution of the surface temperature of the debris layer along the center-line of Khumbu Glacier derived from satellite thermal imagery (Landsat TM band 6, 12 April 1988). Unfortunately, the midstream of the glacier was covered with a small patch of cloud which caused the low temperatures found $3.5-6 \mathrm{~km}$ from EBC. The linear interpolation is shown with a dotted line (Fig. 2) and the result used in the following calculation.

The surface temperature was close to $0^{\circ} \mathrm{C}$ near $\mathrm{EBC}$, where bare ice was exposed or there was a very thin debris layer, increasing gradually toward the terminus with a small peak at the $2.5-3 \mathrm{~km}$ range. This peak corresponded with a transverse debris band separating the pinnacle zone into two (Fig. 1). The spatial pattern of surface temperature reflects the distribution of thermal resistance of the debris layer, which is roughly proportional to the debris thickness. The thickness increases with the distance from EBC (Nakawo and others, 1986). There is an area with relatively lower temperature 8-9.5 km from EBC, where paradoxically the debris thickness was considered to be very large. It was observed in the field that the debris of the terminal area was partly covered with vegetation and rather fine soil particles. During in situ observations, it seemed to be wetter than the other sites of the debris. The lower temperature could be caused by reduced latent heat associated with evapotranspiration from the surface, which would be much more intense than where the debris surface appeared to be dry.

The thermal resistance along the center-line of the ablation area was estimated by Equations (1) and (2), for which unpublished meteorological data, measured by the Glaciological Expedition in Nepal (GEN) from 1973 to 1976 (Higuchi, 1993), was used. It was assumed in the estimation that meteorological conditions at the time of satellite data retrieval were the same as those averaged for the same time in the same season in different years, since no data were available for that particular time. Based on the distribution of thermal resistance $R$, ablation under the debris layer was calculated for one year. Meteorological data were taken from limited data given by the Nepal Department of Hydrology and Meteorology (DHM, 1993), Inoue (1976) and unpublished data by GEN, since no consistent continuous data covering one full year are available. In the calculation, latent-heat flux was neglected since the debris surface is mostly dry. Different albedo values were used: 0.5 for bare ice; 0.1 for schistic debris; 0.2 for granitic debris. 


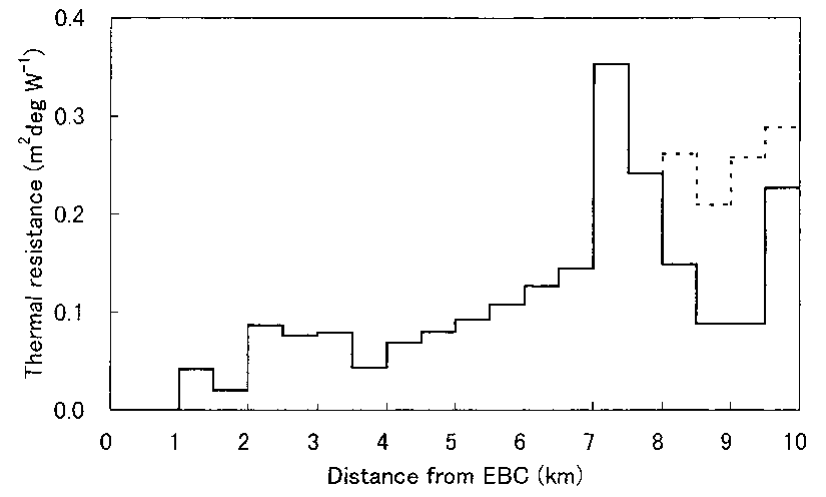

Fig. 3. Thermal resistance for every $0.5 \mathrm{~km}$ interval. Solid line showe calculation neglecting latent-heat flux. Dotted line that when latent-heat flux in wet areas is accounted for.

The longitudinal distribution of thermal resistance and annual ablation along the center-line are shown with a solid line in Figures 3 and 4, respectively. The annual ablation is very low near EBC, but increases downstream, having a

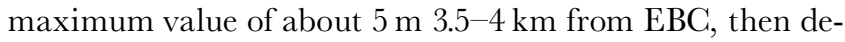
creases towards the terminus. Near the terminus, another peak can be seen which is probably caused by neglecting the latent-heat flux, since the area was rather wet in contrast to the other area. Re-calculation of thermal resistance, as well as ablation rate, taking into account the latent-heat flux, resulted in the dotted line shown in the figures. Thermal resistance increases gradually toward the terminus. The ablation rate roughly agrees with both the observations by Müller (1968) and Inoue and Yoshida (1980).

\section{Ice flow}

Various surface micromorphologies were identified over the ablation area of the glacier on SPOT (système probatoire pour l'observation de la terre) HRV (high resolution visual) panchromatic images $(10 \mathrm{~m}$ spatial resolution, 19 January 1987 and 9 November 1993). By comparing the location of the same feature in two images, the distribution of the surface velocity was estimated. In the process, a different feature may be misread as the same feature when comparing the two images. Hence, flow vectors whose direction differed from that of the center-line of the glacier by more than 30 degrees were discarded; this accounted for roughly one-

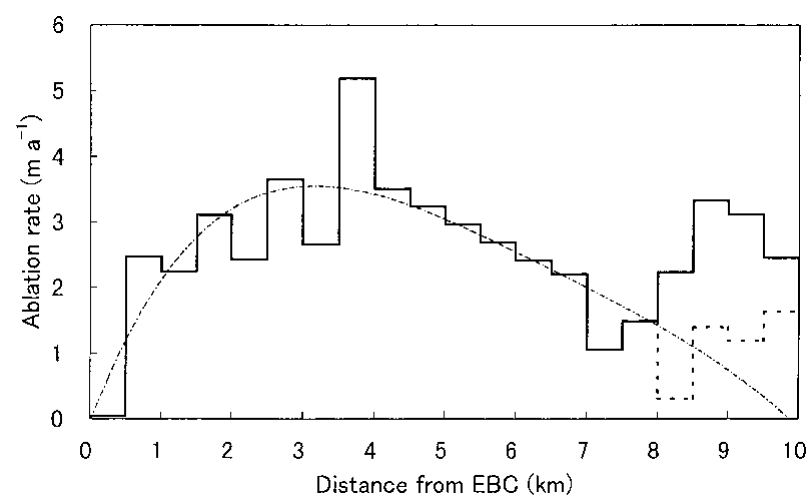

Fig. 4. Annual ablation estimated for every $0.5 \mathrm{~km}$ interval. Solid line shows calculation neglecting latent-heat flux. Dotted line that when latent-heat flux in wet areas is accounted for. The approximation of the profile is shown with the dash-and-dot line which is used for further calculation.

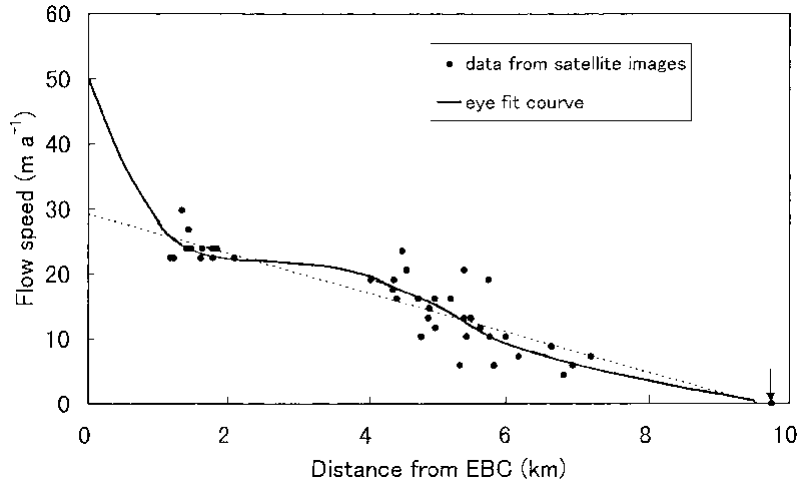

Fig. 5. Surface velocity estimated from SPOT HRV panchromatic images, 19 January 1987 and 9 November 1993. Visually fitted curve and linear regression line are shown with solid and dotted lines, respectively. Arrow indicates apparent terminus.

third of the data. Among the flow vectors obtained, those near the center-line of the glacier were selected and are presented in Figure 5 with dark spots.

Flow speed was $20-30 \mathrm{~m} \mathrm{a}^{-1} 1$ to $2 \mathrm{~km}$ from EBC and decreased down-glacier almost linearly with the increase in distance from EBC. These values are roughly compatible with, but slightly smaller than, the earlier data obtained at sites around the pinnacle zone. At downstream sites, only two survey data are available (Kodama and Mae, 1976). They observed velocities of about $20 \mathrm{~m} \mathrm{a}^{-1}$ and $1 \mathrm{~m} \mathrm{a}^{-1}$ at about $5 \mathrm{~km}$ and $8.5 \mathrm{~km}$ from EBC respectively, which compare with our result. The solid line in Figure 5 represents a visual fit to the data, taking into account the velocity of about $50 \mathrm{ma}^{-1}$ near EBC recently obtained by Seko and others (1998), which is smaller than but almost consistent with the survey data of Müller (1968) and Kodama and Mae (1976).

\section{Change in ice thickness}

Ice-thickness data obtained by Moribayashi (1978) are plotted in Figure 6, with the widths of the glacier and the area between the side moraines measured from the topographical map published by the National Geographic Society (1988). With these data, combined with ablation rate data and satellite-derived velocities, the change in ice thickness can be estimated with the following continuity equation:

$$
\frac{\partial(\alpha W h)}{\partial t}=b(\alpha W)-\frac{\partial(\alpha W h v)}{\partial x}
$$

where $W$ is the width of glacier surface, $h$ is ice thickness, $b$ is the surface balance which is equivalent to ablation rate in our calculation, $v$ is mean velocity, $x$ is longitudinal distance taken positive downward, and $t$ is time. The calculation was made for a central part of the glacier along the center-line, and $\alpha$ is the proportionality constant of the width of the central part in question to the glacier width $W$. For simplicity, it was assumed that the mean velocity was not much different from the surface velocity. In the calculation, made for every $0.5 \mathrm{~km}$ increment, the approximation curve, shown with the dash-and-dot line in Figure 4, was used for $b$, and the velocity curve $v$ was fitted by eye.

The result shown in Figure 7 indicates the glacier surface is lowering throughout the ablation area. The rate is large near EBC, roughly $1-2 \mathrm{~m} \mathrm{a}^{-1}$, and decreases down-glacier with a peak $3-5 \mathrm{~km}$ from EBC. In the area with thick supra- 

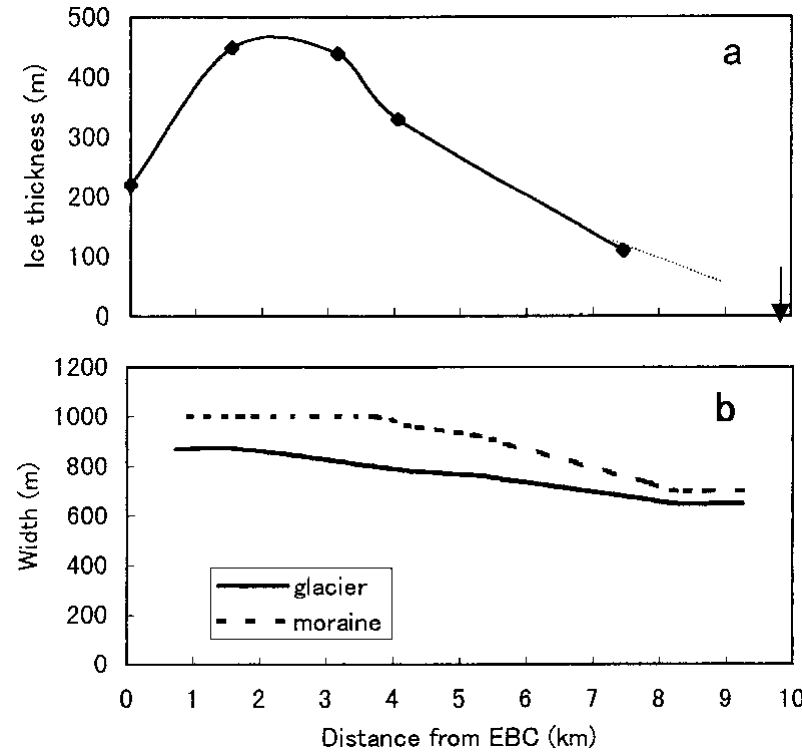

Fig. 6. (a) Ice thickness and (b) glacier width, with and without side moraines. Ice-thickness data ( $\bullet$ ) are from Moribayashi (1978). Solid line is interpolated and dotted line extrapolated toward the terminus. Both lines were used to calculate surface lowering. Arrow indicates apparent terminus.

glacial debris, the rate is not much different from place to place, about $1 \mathrm{~m} \mathrm{a}^{-1}$.

\section{DISCUSSION}

At debris-free glaciers, the ablation rate increases with decreasing elevation downstream. The longitudinal distribution of ablation on debris-covered glacier is quite different (Fig. 4). This is considered a result of the insulating effect of the supraglacial debris layer. The trend of decrease in ablation with distance, however, is rather gentle. Earlier investigations showed that the ablation rate under debris, about $0.1 \mathrm{~m}$ thick, was roughly one-tenth of that for bare ice; under about $1 \mathrm{~m}$ thick the ablation became negligible (e.g. Mattson and others, 1993). The ratio is dependent on both the thermal properties of the debris and the meteorological parameters (Nakawo and Takahashi, 1982). This was confirmed by Inoue and Yoshida (1980) in the ablation area of Khumbu Glacier. Therefore, the ablation rate should decrease very rapidly with the distance, since debris thickness was more than $1 \mathrm{~m}$ in the lower half of the ablation area of Khumbu Glacier (Nakawo and others, 1986).

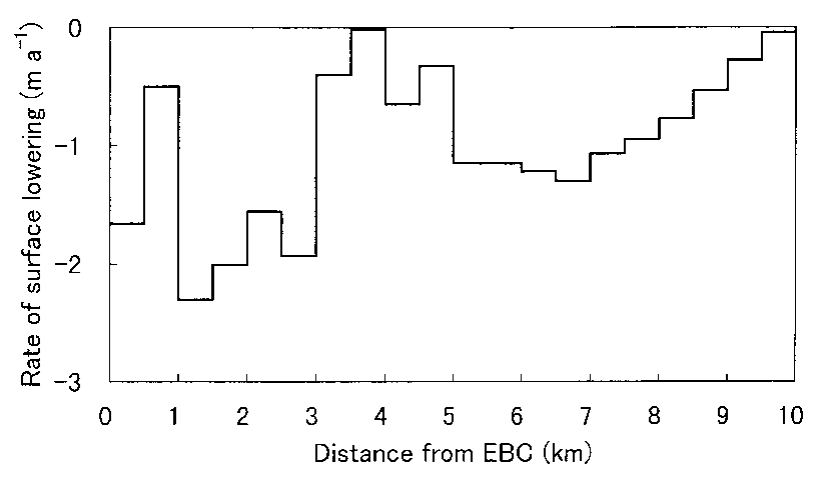

Fig. 7. Surface lowering. Visually fitted curve in Figure 5 was used for velocity.
Sakai and others (1998) assessed the contribution of the ablation at ice cliffs surrounding supraglacial lakes to the total ablation of the debris-covered area of a glacier in the Nepal Himalaya. It was concluded recently that melting at ice cliffs accounted for $20 \%$ of the total ablation of the debris-covered area, although the ratio of the cliffs was only $2 \%$ of the total area. For Khumbu Glacier, where the area of ice cliffs accounts for $2.6 \%$ of the total, melting at ice cliffs should also contribute significantly to the average ablation of the debris-covered area (Inoue and Yoshida, 1980), and the decreasing trend downstream should be small. In the area with thick debris, there are many supraglacial lakes, which change their locations frequently (Seko and others, 1998). One of the advantages of estimating ablation under a debris layer from the surface temperature data is that the averaged surface temperature can lead to a realistic averaged ablation rate over a heterogeneous surface, such as a mixture of ice cliffs, lakes and debris-covered surfaces, where ablation rates differ significantly from place to place (Nakawo and others, 1993).

Satellite imagery for estimating surface-flow velocity is useful and advantageous for debris-covered glaciers where in situ observations are difficult or dangerous. Seko and others (1998) have also estimated ice velocity from satellite images in the pinnacle zone, which generally agrees with our result. They compared the velocity data obtained with the earlier survey data by Müller (1968) and Kodama and Mae (1976), and concluded that flow rates seem to have decreased in the last few decades in the area down to about $3 \mathrm{~km}$ from EBC, although appreciable temporal change was not detected with our data at downstream sites, where velocities were rather small.

The thinning of the glacier could be the cause of the decrease in velocity, since surface flow is roughly proportional to the 4th power of ice thickness. According to Seko and others (1998), the rate of decrease in velocity was about $13 \mathrm{~m} \mathrm{a}^{-1}$ around $\mathrm{EBC}$, and about $6 \mathrm{~m} \mathrm{a}^{-1} 2 \mathrm{~km}$ from EBC, over three decades shown in Figure 8. Near EBC, where the ice is $200-300 \mathrm{~m}$ thick, the rate of velocity decrease could be caused by the thinning rate of about $0.5 \mathrm{ma}^{-1}$, assuming no basal sliding and constant surface slope. For the site $2 \mathrm{~km}$ from $\mathrm{EBC}$, the rate of velocity decrease can be attributed to a thinning of about $1 \mathrm{ma}^{-1}$. These values are of the same order of magnitude for surface lowering rate as those shown in Figure 7. Also the rate is roughly twice as large at the lower site than near EBC, similar to Figure 7.

Detailed surface mapping was carried out in 1978 (Watanabe and others, 1980), and the glacier was resurveyed in 1995. The surface lowering detected over the 17 years was (personal communication from T. Kadota, 1998): in the pinnacle zone $10-30 \mathrm{~m}\left(0.6-1.8 \mathrm{~m} \mathrm{a}^{-1}\right.$ on average $) ; 4 \mathrm{~km}$ from EBC about $8 \mathrm{~m}\left(0.5 \mathrm{~m} \mathrm{a}^{-1}\right.$ on average $) ; 6 \mathrm{~km}$ from EBC about $10 \mathrm{~m}\left(0.6 \mathrm{~m} \mathrm{a}^{-1}\right.$ on average); and $9 \mathrm{~km}$ from EBC about $3 \mathrm{~m}$ $\left(0.15 \mathrm{~m} \mathrm{a}^{-1}\right.$ on average). The spatial distribution of thinning is very similar to our calculation, although the magnitude is not the same.

The difference in magnitude is caused mainly by uncertainty in meteorological conditions in the ablation-rate calculations, because continuous year-round meteorological data were not available. When the meteorological conditions were changed, the resultant rate of lowering altered accordingly. It is considered, therefore, that absolute values of calculated surface lowering may be in error. The characteristics of the longitudinal distribution, however, should be comparatively 
reliable, since the spatial variation in meteorological conditions, although not known exactly, would be small.

One of the characteristics shown in Figure 7 is that the lowering takes place almost uniformly in the debris-covered area, particularly where debris thickness is large, even though debris thickness increases down-glacier quite rapidly. This would be due mainly to the contribution of melting at ice cliffs as discussed previously. This indicates that this part of the glacier, whose ice thickness is a few hundred meters in the ablation area, might disappear in a century or so, even with the current meteorological conditions. We are not sure whether the air temperature has increased lately in the Himalaya in association with global warming. If this did happen, but precipitation remained the same, the glaciers would retreat much more rapidly.

In the Lirung drainage basin, the amount of river discharge exceeded the total precipitation into the basin by about 30\% (Rana, 1997). It was augmented by shrinkage of Lirung Glacier, a debris-covered glacier. Debris-covered glaciers are thus playing a role in supplying additional water, without which the discharge would be much smaller. Disappearance of the glaciers would also damage the scenery which attracts many tourists. Therefore, careful attention needs to be paid to the evolution of debris-covered glaciers, since they account for more than half of the total glacierized area in the Nepal Himalaya.

\section{AGKNOWLEDGEMENTS}

An intensive study of the supraglacial debris of Khumbu Glacier was proposed in 1977 by the first author of this paper. The plan was implemented in 1978, but he was not able to participate. The 1978 results form the basis of this paper. The authors would like to express sincere thanks to many colleagues who carried out investigations in 1978, particularly O. Watanabe, the field leader. Thanks are due to T. Kadota, who provided data obtained in 1995 as part of the Himalayan Cryosphere Research Expedition. The authors are also indebted to two reviewers whose suggestions improved the paper. Financial support was provided by a Grant-in Aid for Scientific Research (No. 09490018) from the Ministry of Education, Science, Sports and Culture, Japanese Government, and Cooperative Research under

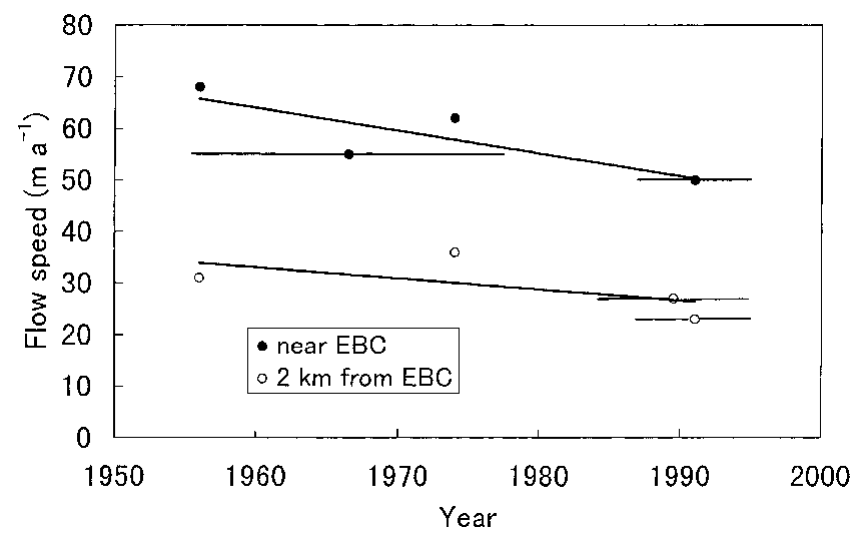

Fig. 8 Decreasing trend of velocity near EBC and around icepinnacle zone. Data are from Seko and others (1998). The period of observation is marked by a horizontal bar with a symbol in the middle of the time. the Japan-US Cooperative Science Program from the Japan Society for the Promotion of Science.

\section{REFERENGES}

Fushimi, H. 1977. Structural studies of glaciers in the Khumbu region. Seppyo, 7. Jpn. Soc. Snow Ice, Special Issue 39, 30-39.

Fushimi, H., M. Yoshida, O. Watanabe and B. P. Upadhyay. 1980. Distributions and grain sizes of supraglacial debris in the Khumbu glacier, Khumbu region, Nepal. Seppyo, 7. Jpn. Soc. Snow Ice, Special Issue 41, 18-25.

Hall, D. K., J. P. Ormsby, R. A. Bindschadler and H. Siddalingaiah. 1987. Characterization of snow and ice reflectance zones on glaciers using Landsat thematic mapper data. Ann. Glaciol., 9, 104-108.

Higuchi, K. 1993. Nepal-Japan cooperation in research on glaciers and climates in the Nepal Himalayas. International Association of Hydrological Sciences Publication 218 (Symposium at Kathmandu 1992 - Snow and Glacier Hydrology), 29-36.

Higuchi, K., S. Mae and H. Kodama. 1978. Utolshchenie lednika Kkhumbu, stekaiushchego s gory Everest / The thickening of Khumbu Glacier flowing from Mt. Everest, east Nepal. Mater. Glyatsiol. Issled.33, 107-112 (Russian), 171-175 (English).

Inoue, J. 1976. Climate of Khumbu Himal. Seppyo, J. Jpn. Soc. Snow Ice, Special Issue 38, Part I, 66-73.

Inoue, J. and M. Yoshida. 1980. Ablation and heat exchange over the Khumbu glacier. Seppyo, 7. Jpn. Soc. Snow Ice, Special Issue 41, 26-33.

Iwata, S., O. Watanabe and H. Fushimi. 1980. Surface morphology in the ablation area of the Khumbu glacier. Seppyo, J. Jpn. Soc. Snow Ice, Special Issue 41, 9-17.

Kodama, H. and S. Mae. 1976. Flow of glaciers in the Khumbu region. Seppyo, 7. Jpn. Soc. Snow Ice, Special Issue 38, Part I, 31-36.

Mattson, L. E., J. S. Gardner and G. J. Young. 1993. Ablation on debris covered glaciers: an example from the Rakhiot Glacier, Punjab, Himalaya. International Association of Hydrological Sciences Publication 218 (Symposium at Kathmandu 1992 - Snow and Glacier Hydrology), 289-296.

Moribayashi, S. 1978. Transverse profiles of Khumbu Glacier obtained by gravity observation. Seppyo, 7. Fpn. Soc. Snow Ice, Special Issue 40, 21-25.

Müller, F. 1968. Mittelfristige Schwankungen der Oberflächengeschwindigkeit des Khumbugletschers am Mount Everest. Schweiz. Bauztg., 86(31), 569-573.

Nakawo, M., S. Iwata, O. Watanabe and M. Yoshida. 1986. Processes which distribute supraglacial debris on the Khumbu Glacier, Nepal Himlaya. Ann. Glaciol., 8, 129-131.

Nakawo, M., T. Morohoshi and S. Uehara. 1993. Satellite data utilization for estimating ablation of debris covered glaciers. International Association of Hydrological Sciences Publication 218 (Symposium at Kathmandu 1992 - Snow and Glacier Hydrology), 75-83.

Nakawo, M. and S. Takahashi. 1982. A simplified model for estimating glacier ablation under a debris layer. International Association of Hydrological Sciences Publication 138 (Symposium at Exeter 1982 - Hydrological Aspects of Alpine and High Mountain Areas), 137-145.

Nakawo, M. and G. J. Young. 1981. Field experiments to determine the effect of a debris layer on ablation of glacier ice. Ann. Glaciol., 2, 85-91.

Nakawo, M. and G. J. Young. 1982. Estimate of glacier ablation under a debris layer from surface temperature and meteorological variables. F. Glaciol., 28(98), 29-34.

National Geographic Society. 1988. Mount Everest. Washington, DC, National Geographic Society.

Nepal,Ministry of Water Resources. 1993. Snow and glacier hydrology year book 1987-1992. Kathmandu, Nepal, Ministry of Water Resources. Department of Hydrology and Meteorology.

Rana, B. 1997. Study of glacier ablation under debris-cover for runoff modeling of a river basin in Langtang Valley, Nepal Himalaya. (Ph.D. thesis, Nagoya University.)

Rana, B., M. Nakawo, Y. Fukushima and Y. Ageta. 1997. Application of a conceptual precipitation-runoff model (HYCYMODEL) in the debriscovered glacierized basin in the Langtang Valley, Nepal Himalaya. Ann. Glaciol., 25, 226-231.

Sakai, A., M. Nakawo and K. Fujita. 1998. Melt rate of ice cliffs on the Lirung Glacier, Nepal Himalayas, 1996. Bull. Glacier Res. 16, 57-66.

Seko, K., H. Yabuki, M. Nakawo, A. Sakai, T. Kadota and Y. Yamada. 1998. Changing surface features of Khumbu Glacier, Nepal Himalayas revealed by SPOT images. Bull. Glacier Res. 16, 33-41.

Watanabe, O. and 7 others. 1980. Outline of debris cover project in Khumbu Glacier. Seppyo, 7. Jpn. Soc. Snow Ice, Special Issue 41, 5-8.

Watanabe, O., S. Iwata and H. Fushimi. 1986. Topographic characteristics in the ablation area of the Khumbu Glacier, Nepal Himlaya. Ann. Glaciol., 8, 177-180. 